\title{
(In)Visible Tourism According to Online Cash Registers in Hungary, 2018-2020
}

\author{
Géza Tóth ${ }^{1,2}$ (1) and Áron Kincses $1,2, *$ (]) \\ 1 Institute of World and Reginal Economics, University of Miskolc, 3515 Miskolc, Hungary; geza.toth@ksh.hu \\ 2 Hungarian Central Statistical Office, Statistics Directorate, 1024 Budapest, Hungary \\ * Correspondence: aron.kincses@ksh.hu
}

Citation: Tóth, G.; Kincses, Á. (In)Visible Tourism According to Online Cash Registers in Hungary, 2018-2020. Sustainability 2022, 14 , 3038. https://doi.org/10.3390/ su14053038

Academic Editors: Anna Rita Irimiás, Dallen J. Timothy and Gábor Michalkó

Received: 4 February 2022

Accepted: 1 March 2022

Published: 4 March 2022

Publisher's Note: MDPI stays neutral with regard to jurisdictional claims in published maps and institutional affiliations.

Copyright: () 2022 by the authors Licensee MDPI, Basel, Switzerland. This article is an open access article distributed under the terms and conditions of the Creative Commons Attribution (CC BY) license (https:// creativecommons.org/licenses/by/ $4.0 /)$.

\begin{abstract}
The aim of this paper is to share innovations and some key lessons learned in the use of non-traditional data sources to improve data quality and enable more accurate and efficient data use in the field of tourism. Research on visitor traffic is based on classical statistical measures, but it may be worth expanding it with alternative data sources, such as databases based on online cash register (OCR) data. These data can be particularly useful for analysing tourism-related consumption habits in a given area. The study introduces the "invisible", tourism-related, non-accommodation spending characteristics of transit traffic in Hungary, the possibilities of its analysis and spatial aspects, using online cash register data (includes all retail sales in Hungary, except for motorcycle purchases), and additionally, we identify the most affected municipalities which are invisible for traditional data sources. The results show that invisible tourism, linked to transit traffic, has significant economic potential. The analysis of this new type of database will provide a more accurate and faster picture of consumption associated with hidden tourism, which can be an important input for economic and marketing development.
\end{abstract}

Keywords: invisible tourism; transiting; transit traffic; geospatial information; Hungary

\section{Introduction}

Hungary is a transit country, not only for freight but also for passengers. About one third of foreigners entering Hungary each year only pass through the country. This is explained by Hungary's central location in East-Central Europe, its proximity to seven countries and its access to the European road network. Transit does not necessarily occur in a hermetically sealed corridor-such as motorways across national borders-almost isolated of the socio-economic environment, but often becomes part of it. The nature of the transit implies stops, longer or shorter breaks for the driver and passengers, meals and refuelling of the vehicle, which take place both in motorway car parks with appropriate infrastructures and in the living areas of the local population within residential areas.

Classic survey-based data sources are available for the travel activity of foreigners not involved in freight transport, so we have a relatively reliable picture of the macro-level characteristics of transit flows. According to data from the Hungarian Central Statistical Office, the share of transit passengers arriving in Hungary increased from 33\% in 2017 to $34 \%$ in 2020. Their number exceeded 20 million in 2019, before the COVID-19 pandemic, and decreased to 11 million in 2020. Spending by transit passengers accounted for $6 \%$ of total spending in 2017, increasing to $9 \%$ by 2020. Spending was HUF 116 billion in 2017, rising to HUF 174 billion in 2019, and then decreased to just over HUF 104 billion in 2020. The indicators speak for themselves: traffic of this magnitude is capable of generating changes at the micro-level, with social, economic and physical impacts [1] on the life of the municipalities concerned. However, in order to examine these effects, it is essential to define the municipalities involved in transit traffic, i.e., to identify the towns and villages where the demand of transit passengers is realised. 


\section{Materials and Methods}

\subsection{Online Cash Register Data in Hungary}

The challenges faced by statistics in the 21st century are manifold. We are surrounded by systems that are becoming substantially more and more complex. With the emergence of new phenomena (e.g., globalisation, global demographic trends or sustainable development) and complex realities that need to be meaningfully and timely captured by statistics, new types of data have also been emerging, offering opportunities to improve the relevance of statistics.

Fortunately, there is currently an abundance of data sources: questionnaire-based statistical data, census data, big data, smart data, machine data, administrative data, privately held data, etc. In many cases, statistical domains are based on traditional data sources that are reaching their limits with respect to timeliness, relevance and compliance.

For the purpose of reducing the abuses committed during the retail trade turnover, the government of Hungary decided to introduce an online connection of cash registers with the National Tax Authority in October 2014. According to the OECD [2], electronic cash registers are used (among others) in Argentina, Austria, Belgium, the Czech Republic, Hungary, Italy, the Netherlands, Portugal, Russia and Sweden. As such, cash machines involved in the online cash register system send online retail chain sales information to the National Tax Authority. This means that data concerning the sales of retail stores can be accessed in real time from the NTCA (National Tax and Customs Administration) database. Immediately after the purchase of goods or services, invoice details are automatically sent online to the National Tax and Customs Administration. The Hungarian Central Statistical Office receives this in full. The database contains the OCR number, the date of commissioning, the period of validity, the tax number of the company, the name and address of the business, the economic activity of the company, the number and turnover value of invoices, cancellation and returns for the given period.

In this paper, we use OCR data from 2018, 2019 and 2020 to illustrate methodological approaches that map out the crystallisation points of transit traffic in Hungary. While the study primarily aims to capture the phenomenon of transit at the municipal level, we draw attention to the fact that the impacts are economy-wide in their multiplier effect.

The OCR data are available up-to-date, with the added advantage of being disaggregated by economic activity and geographical location. The advantage of online cash registers is that tax authorities can determine the amount of tax payable more accurately and quickly based on the data they receive, and if they see suspicious traffic data, they will be able to filter out fraudsters in a matter of seconds. The system developed from a tax point of view also provides much more accurate data for analysis, so we used this data source. According to the OECD [2], the use of online cash registers has the following advantages: better tax compliance, protection of fair competition, reduction of compliance burdens, and enhanced consumer protection. The other advantage of OCR is that we have quasi-real-time information about retail processes, the time to market is much faster than the classic questionnaire survey, and it reduces the statistical reporting burden on businesses.

The disadvantage of OCR data is that due to possible failures of the cash machines, NTCA will not receive data for another 11 months, so the first data transmission cannot be considered as final information. However, the differences between data sets are now negligible.

For the purpose of this study, we consider tourism-related expenditures based on the international recommendations (https://unstats.un.org/unsd/publication/Seriesm/ SeriesM_83rev1e.pdf) (accessed on 5 January 2022) presented in Appendix A Table A1.

Transiting is a relatively rarely analysed part of tourism, despite the unquestionable importance of connectivity in tourism systems [3]. One of the reasons for this, according to certain opinions, is that transit is partly seen as a low revenue generator and partly as a necessary inconvenience for tourists [4]. 


\subsection{Theoretical Background}

Although transit is a phenomenon that affects many countries in Europe, the study of this kind of mobility is not part of mainstream national and international research on transport, migration and tourism. Some of the studies on transit issues focus on freight transport infrastructure and its development [5,6] and logistics [7], while others focus on cost implications [8-11], environmental issues [12] and geopolitical aspects [13,14]. Researchers are much more interested in exploring the specificities of traffic flowing through large cities [15-17] than that between national borders.

Transiting is a specific form of mobility, as its main purpose is to cover the distance between the origin and the destination in the shortest possible time, while travellers usually do not consider the tourist experiences they may have on the way. However, transit does not exclude the use of the tourist services of the areas concerned, since transit passengers may interrupt their journey to buy fuel or to visit retail shops, but we should not forget the possibility of visiting certain tourist attractions and, in some cases, of using accommodation facilities [18-21]. Same-day movements are distinguished more by their duration and less by their radius. With minimal investment, same-day trips will meet tourist demand, and thus contribute to the development of tourism in general [22].

Tourism researchers have a surprisingly lenient approach to the issue of transit, which is certainly related to the statistical interpretation of the concept [23]. There are hardly any studies that have recognised the tourism implications of the behaviour of transit passengers. This topic is mainly addressed in studies on tourism in the former socialist countries of Central and Eastern Europe and South-Eastern Europe, where the flow of guest workers to the West is also highlighted [24-26].

Transiting is a key phenomenon not only in land transport but also in water [27] and air transport, with retail stores available from airport transit lounges, serving both to spend time and to encourage spending by transit passengers [28-31]. Researchers are also interested in the measurement of transit traffic, which, while not a potential substitute for classical traffic counting, can provide a useful complementary source of information from the spatial- and time-based recording of call volumes over a wide range of mobile communication devices [32]. Last, but not least, the specific tourist behaviour of caravans and motorhomes is unexplored in the relationship between tourism and transit [33].

Although our study tries to delimit the range of settlements that primarily benefit from transit tourism, we also consider it important to mention that transit has its drawbacks, the management of which is definitely a challenge for decision-makers. Such a challenge could be increased traffic, the resulting congestion, high levels of pollution, etc. This, in turn, leads us to the issue of tourism penetration [34], which may be the subject of further research.

\subsection{Transiting as a Crypto Mobility Activity}

The tourism aspects of this phenomenon have also been recognised by relevant EU experts, who have suggested, among other things, the need to measure transit travel. Recital 5 of the EU regulation (Regulation (EU) No 692/2011 of the European Parliament and of the Council of 6 July 2011 concerning European statistics on tourism and repealing Council Directive 95/57/EC) to modernise the methodology of tourism statistics states that:

"The changing nature of tourism behaviour ... with the growing importance of short trips and same-day visits contributing substantially in many regions or countries to the income from tourism [ ... ] means that the production of tourism statistics should be adapted."

The previous definition of tourism, which assumed a minimum one-night stay, therefore needs to be amended to take into account not only so-called "excursion" traffic (shopping, visiting relatives), which is mainly concentrated in border areas and lasts less than $24 \mathrm{~h}$, but also transit traffic. Since the paradigm of thinking about tourism [35] excludes the discussion of the demand arising from the needs of freight transport actors and the supply created to satisfy them under the umbrella of tourism, it is still appropriate to ignore freight transport. 
However, it should be noted that road corridors for freight transport include a number of infrastructure and suprastructure objects that are also used by lorry drivers. Thus, petrol stations offering complex services, roadside accommodation and catering outlets meet the demand not only of passengers but also of freight transport. Therefore, in a certain context, it is appropriate to carry out an analysis in this respect, even if the demand generated by freight transport is not considered as tourism expenditure.

If passenger transit is discussed as part of tourism, it is assumed that similar to conventional tourist mobility; it has its clear manifestations. However, while the fact of staying in a registered accommodation is included in tourism statistics, services used in unconventional tourism mobility rarely become part of a database that can be compared over space and time. The exploration of the territorial aspects of transiting, therefore, requires the creation of a methodological approach which, on the one hand, takes into consideration the specificities of the phenomenon under study and, on the other hand, is based on some statistically measurable fact. The challenge is not a minor one, as we need to make visible a crypto mobility, a quasi-invisible travel phenomenon. In our approach, we consider areas that are covered by official statistical data collection as visible tourism areas, and those that are not covered by official data collection as invisible tourism areas (for example: trips shorter than $24 \mathrm{~h}$, border trips, the use of friendly accommodation). Within these, the present study deals mainly with the issue of transit.

For this, it is worth starting with the characteristic feature of transit that captures the moment of stopping for whatever reason. Buying fuel or shopping in retail stores is definitely one of them, but we should also bear in mind visiting certain tourist attractions and, in some cases, staying in accommodation. However, there is no statistical data on the number of visitors to each municipality, so in these cases only the OCR can provide a useful indication.

\subsection{Delineation of the Municipalities Involved in Transiting Using GIS Methods}

The first step of the analysis was to identify the Hungarian settlements that could be affected by transit traffic. The delineation was carried out using geographic information methods and taking into account the following criteria:

(a) When a transit traveller enters Hungary at a road border crossing point, he or she does not leave Hungary at the same border crossing point from which he or she arrived.

(b) Due to the nature of transit, it was also assumed that a person transiting through Hungary would use the shortest route in time between the entry and exit points.

Based on these criteria, the shortest travel time to all border crossing points in all neighbouring countries was determined. The municipalities affected by the intersection of each route were selected and summarised. The possibility was considered that transit traffic might benefit not only the settlements directly affected by transport routes, but also neighbouring settlements. However, we considered this to be an isolated and ad hoc phenomenon and the original delineation was therefore considered sufficient. Based on this delineation, 956 of Hungary's 3152 settlements were included in the scope of the study, i.e., this was the number of municipalities considered as potential crystallisation points for transit traffic, and further investigations were carried out on this population of municipalities.

\section{Outcomes, Results}

\subsection{Exploring the Role of Tourism by Expert Assessment}

The 956 municipalities included in the study were classified into three groups based on expert assessment of the role of the tourist attractions located in their administrative territory. Given that presenting the methodology of the expert assessment of tourism attractiveness would go far beyond the scope of this study, we will only outline the main points of the assessment carried out. Our work was based on the recommendations of the methodological handbook (compiled by Gábor Michalkó and Tamara Rátz), which was prepared in 2006 under the co-ordination of Hungarian Tourism Ltd. In this case, for the 
classification of individual attractions, legislation (e.g., Act CXII of 2000 on the adoption of the Spatial Planning Plan of the Balaton Special Tourist Region and on the establishment of the Balaton Spatial Planning Code), official databases (e.g., the National Public Health and Medical Officer's Service, the Registry of the National Directorate General for Spas and Thermal Baths), surveys and registers of the HCSO (e.g., the number of overnight stays and offer of spa and wellness hotels), ratings published by professional organisations (e.g., the list of certified festivals of the Hungarian Festival Association) and the websites of the municipalities were used. For example, international and national ratings were awarded to those municipalities whose accommodation demand was dominated by foreign demand, which had the highest ranking in the various databases (e.g., settlement by Lake Balaton; spa; wellness hotel; festival with excellent rating). Municipalities with regional attractiveness include those towns and villages that were rated lower in the sources reviewed (e.g., settlement further from Lake Balaton, no spa, but there was thermal water for bathing; well-rated festival). The municipalities that were not included in the databases we processed and whose attractiveness could not be identified from the information on their websites were grouped into municipalities without significant tourist attractions. The first group included international and national attractiveness, the second group was made up of regional attractiveness and the third group contained municipalities without significant tourist attractions (see Figure 1). The data used in the following analysis were derived from the above settlement classification of the role of tourism attraction and the settlement aggregation of the OCR data related to tourism (see Tables 1-3).

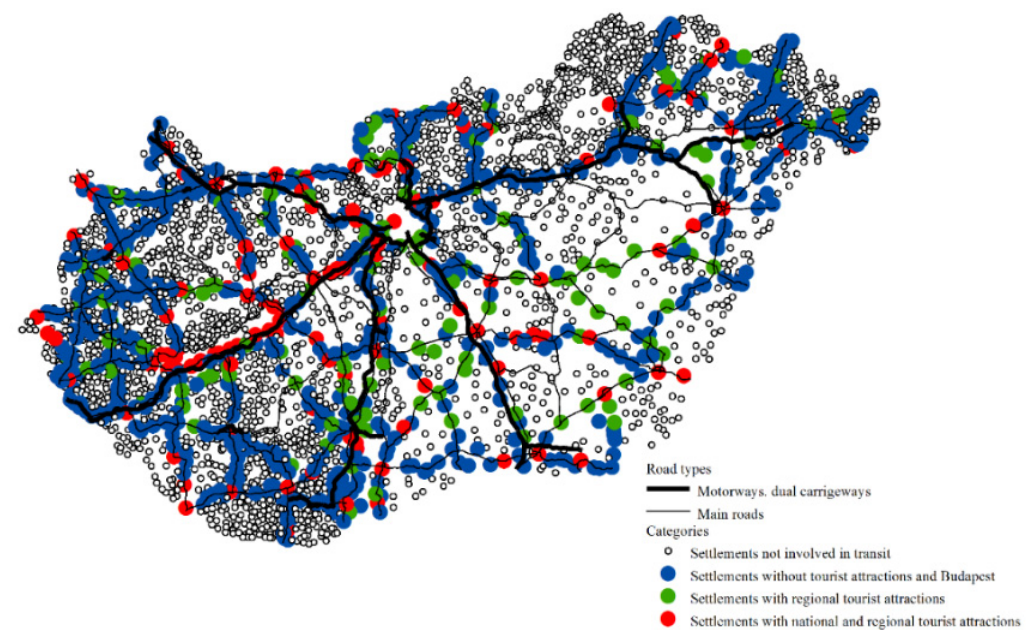

Figure 1. The Hungarian municipalities according to their tourism attractiveness.

Table 1. Number of surveyed municipalities as a function of tourism-related revenue and the tourism attractiveness category in 2018.

\begin{tabular}{|c|c|c|c|c|c|c|c|}
\hline Category/Revenue & $\begin{array}{c}\text { HUF } \\
0-50 \\
\text { Million }\end{array}$ & $\begin{array}{c}\text { HUF } \\
50-250 \\
\text { Million }\end{array}$ & $\begin{array}{c}\text { HUF } \\
\text { 250-500 } \\
\text { Million }\end{array}$ & $\begin{array}{c}\text { HUF } \\
500-1000 \\
\text { Million }\end{array}$ & $\begin{array}{c}\text { HUF } \\
\text { 1000-5000 } \\
\text { Million }\end{array}$ & $\begin{array}{c}\text { HUF over } \\
5000 \\
\text { Million }\end{array}$ & Total \\
\hline $\begin{array}{l}1 \text { (municipalities without } \\
\text { significant attractiveness) }\end{array}$ & 481 & 184 & 31 & 12 & 6 & 0 & 714 \\
\hline $\begin{array}{c}2 \text { (municipalities with regional } \\
\text { attractiveness) }\end{array}$ & 27 & 39 & 17 & 18 & 21 & 3 & 125 \\
\hline $\begin{array}{c}3 \text { (municipalities with national, } \\
\text { international attractiveness) }\end{array}$ & 11 & 20 & 12 & 21 & 34 & 19 & 117 \\
\hline Total & 519 & 243 & 60 & 51 & 61 & 22 & 956 \\
\hline
\end{tabular}


Table 2. Number of surveyed municipalities as a function of tourism-related revenue and the tourism attractiveness category in 2019.

\begin{tabular}{|c|c|c|c|c|c|c|c|}
\hline Category/Revenue & $\begin{array}{c}\text { HUF } \\
\text { 0-50 } \\
\text { Million }\end{array}$ & $\begin{array}{c}\text { HUF } \\
\text { 50-250 } \\
\text { Million }\end{array}$ & $\begin{array}{c}\text { HUF } \\
250-500 \\
\text { Million }\end{array}$ & $\begin{array}{c}\text { HUF } \\
\text { 500-1000 } \\
\text { Million }\end{array}$ & $\begin{array}{c}\text { HUF } \\
\text { 1000-5000 } \\
\text { Million }\end{array}$ & $\begin{array}{c}\text { HUF over } \\
5000 \\
\text { Million }\end{array}$ & Total \\
\hline $\begin{array}{l}1 \text { (municipalities without } \\
\text { significant attractiveness) }\end{array}$ & 465 & 196 & 30 & 15 & 7 & 1 & 714 \\
\hline $\begin{array}{c}2 \text { (municipalities with regional } \\
\text { attractiveness) }\end{array}$ & 27 & 34 & 17 & 20 & 22 & 5 & 125 \\
\hline $\begin{array}{c}3 \text { (municipalities with national, } \\
\text { international attractiveness) }\end{array}$ & 11 & 19 & 9 & 20 & 37 & 21 & 117 \\
\hline Total & 503 & 249 & 56 & 55 & 66 & 27 & 956 \\
\hline
\end{tabular}

Sources: Own calculations, based on OCR register.

Table 3. Number of surveyed municipalities as a function of tourism-related revenue and the tourism attractiveness category in 2020.

\begin{tabular}{|c|c|c|c|c|c|c|c|}
\hline Category/Revenue & $\begin{array}{c}\text { HUF } \\
0-50 \\
\text { Million }\end{array}$ & $\begin{array}{c}\text { HUF } \\
50-250 \\
\text { Million }\end{array}$ & $\begin{array}{c}\text { HUF } \\
\text { 250-500 } \\
\text { Million }\end{array}$ & $\begin{array}{c}\text { HUF } \\
500-1000 \\
\text { Million }\end{array}$ & $\begin{array}{c}\text { HUF } \\
\text { 1000-5000 } \\
\text { Million }\end{array}$ & $\begin{array}{l}\text { HUF over } \\
5000 \\
\text { Million }\end{array}$ & Total \\
\hline $\begin{array}{l}1 \text { (municipalities without } \\
\text { significant attractiveness) }\end{array}$ & 484 & 187 & 25 & 13 & 5 & & 714 \\
\hline $\begin{array}{c}2 \text { (municipalities with regional } \\
\text { attractiveness) }\end{array}$ & 27 & 38 & 16 & 19 & 22 & 3 & 125 \\
\hline $\begin{array}{l}3 \text { (municipalities with national, } \\
\text { international attractiveness) }\end{array}$ & 11 & 20 & 12 & 22 & 35 & 17 & 117 \\
\hline Total & 522 & 245 & 53 & 54 & 62 & 20 & 956 \\
\hline
\end{tabular}

Sources: Own calculations, based on OCR register.

The strength of stochastic relationships between qualitative and quantitative criteria can be measured by association measures $[35,36]$. The independence of the two variables ( $\mathrm{X}$ and $\mathrm{Y}$ ) is then

$$
\Phi^{2}=\sum_{i=1}^{I} \sum_{j=1}^{J} \frac{\left(p_{i j}-p_{i .} \cdot p_{j .}\right)^{2}}{p_{i .} \cdot p_{j .}}
$$

measured by statistics, where $P_{i j}=P\left(\mathrm{X}=\mathrm{x}_{i}, \mathrm{Y}=\mathrm{y}_{j}\right), i=1,2, \ldots . \mathrm{I} ; j=1,2, \ldots, \mathrm{J}$.

If independent, the value is 0 .

Noteworthy statistics are obtained by different normalizations of the quantity $\Phi^{2}$ [37]:

Pearson's formula:

$$
P=\sqrt{\frac{\Phi^{2}}{\Phi^{2}+1}}
$$

Cramer's formula:

$$
T=\sqrt{\frac{\Phi^{2}}{\sqrt{(I-1) \cdot(J-1)}}}
$$

$(P, T=0$ the two variables are independent of each other; $P, T=1$ means a functional relationship, while $0<P, T<1$ indicates a stochastic relationship.)

Based on our calculations (Table 4) using the above theory, we found only a moderately strong stochastic relationship between tourism attractiveness and revenue. Hence, it has been demonstrated that there is no functional relationship between the importance of tourism attractiveness and tourism-related revenues. In fact, there is only a weak stochastic relationship. 
Table 4. Association results between tourism attractiveness and corresponding OCR revenues in the surveyed municipalities.

\begin{tabular}{cccc}
\hline & $\mathbf{2 0 1 8}$ & $\mathbf{2 0 1 9}$ & $\mathbf{2 0 2 0}$ \\
\hline $\mathrm{P}$ & 0.566 & 0.564 & 0.567 \\
$\mathrm{~T}$ & 0.386 & 0.385 & 0.387 \\
\hline
\end{tabular}

Sources: Own calculations.

\subsection{Identification of the Municipalities Involved in Transiting}

In most cases, OCR and attractiveness were proportional at the level of municipalities, but there was a significant anomaly (Tables 1-3). The differences between the above criteria could be distinguished in two directions. In the first case, tourism attractiveness was much higher than the revenue, while in the second case, the municipalities where the revenue significantly exceeded the tourism attractiveness are included. In this study, we will focus on the latter group in more detail.

From Tables 1-3, we consider the municipalities as the crystallisation points of invisible tourism when:

- there was no significant tourist attraction and the corresponding OCR-revenue was above HUF 250 million;

- there was a regional tourist attraction and the above revenue reached or exceeded HUF 1000 million.

These municipalities clearly generate more revenue than would be expected from the role of tourist attractiveness in the area, according to the paradigms of the sector [38], and thus we have identified a group of municipalities that are likely to show a different attitude from conventional tourism.

In 2018, 2019 and 2020, we counted 73, 80 and 68 such municipalities, respectively. The number of municipalities varied slightly over the period. The frequencies of occurrence are shown in Figure 2.

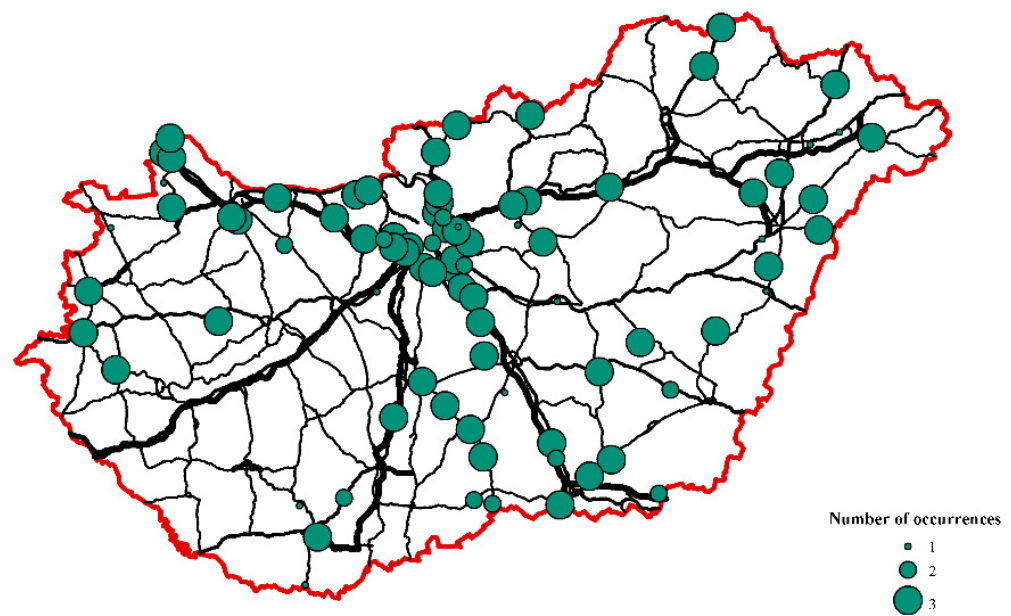

Figure 2. Geographical locations of the surveyed municipalities.

In Hungary, the total value added by the activities included in tourism satellite accounts was 3.4 times higher than the gross value added by tourism in the narrow sense, i.e., accommodation and food service. Based on OCR data, the national ratio was 4.2 for revenues. In 2020, the share of revenues was already 4.7 times for the 956 municipalities analysed. Moreover, in the 68 municipalities identified in 2020, it was more than 10 times higher. This underlines the relevance of the identified municipalities in invisible tourism.

\subsection{Characteristics of the Municipalities Affected by Transit Tourism}

In this section we will further examine the municipalities defined in the previous chapter as the focal points of invisible tourism, in order to identify the characteristics, 
features and geographical locations of the municipalities where transit tourism may become relevant, and the characteristics that increase the chances of transit tourism in a given municipality.

The municipalities affected by transit tourism were highly heterogeneous in terms of population and socio-economic characteristics. We found that the economic and accessibility characteristics of the municipalities did not have a significant impact on the focal points of transit tourism. Therefore, it was assumed that the geographical location of the municipality may play a greater role in transit tourism. In fact, the spatial distribution of the municipalities theoretically affected by transit tourism (956) showed a strong link with road network nodes.

The table below shows: Category 1 -there is a motorway slip road in the municipality, i.e., a main road intersects the motorway; Category 2 -intersection of main roads; and Category 3-all other municipalities located at a point not important for road traffic (Figure 3).

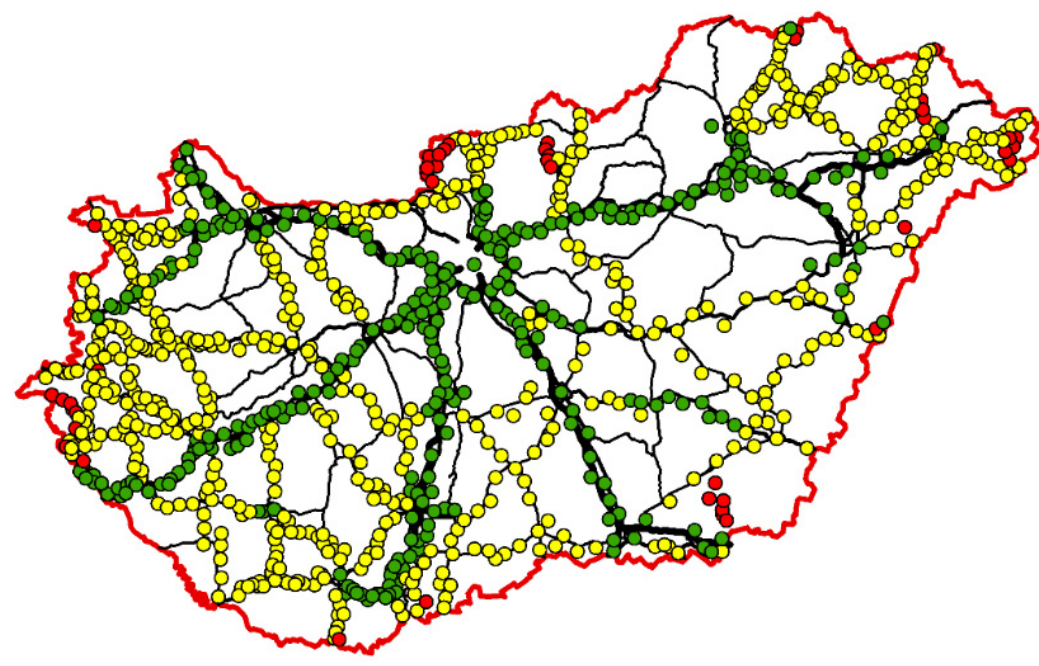

Categories

There is a motorway or a driveway in the settlement

There is a main road access in the settlement

other settlements

Figure 3. Categorisation of Hungarian settlements by road network.

Tables $5-7$ provides a breakdown of the surveyed municipalities by OCR revenue and tourism attractiveness, broken down by the above node categories for the year 2020, highlighting in bold, italic number the municipalities most affected by invisible tourism on the basis of previous analyses. The results for 2018 and 2019 are presented in Appendix A Tables A2-A7.

Table 5. Number of municipalities with motorways and main roads as a function of tourist attractiveness and OCR tourism-related income in 2020.

\begin{tabular}{|c|c|c|c|c|c|c|c|}
\hline Category/Revenue & $\begin{array}{c}\text { HUF } \\
0-50 \\
\text { Million }\end{array}$ & $\begin{array}{c}\text { HUF } \\
50-250 \\
\text { Million }\end{array}$ & $\begin{array}{c}\text { HUF } \\
250-500 \\
\text { Million }\end{array}$ & $\begin{array}{c}\text { HUF } \\
500-1000 \\
\text { Million }\end{array}$ & $\begin{array}{c}\text { HUF } \\
\text { 1000-5000 } \\
\text { Million }\end{array}$ & $\begin{array}{c}\text { HUF over } \\
5000 \\
\text { Million }\end{array}$ & Total \\
\hline $\begin{array}{l}1 \text { (municipalities without } \\
\text { significant attractiveness) }\end{array}$ & 115 & 64 & 14 & 10 & 5 & & 208 \\
\hline $\begin{array}{c}2 \text { (municipalities with regional } \\
\text { attractiveness) }\end{array}$ & 7 & 8 & 7 & 5 & 11 & 2 & 40 \\
\hline $\begin{array}{c}3 \text { (municipalities with national, } \\
\text { international attractiveness) }\end{array}$ & 5 & 6 & 3 & 5 & 20 & 13 & 52 \\
\hline Total & 127 & 78 & 24 & 20 & 36 & 15 & 300 \\
\hline
\end{tabular}


Table 6. Number of municipalities with main roads as a function of tourist attractiveness and OCR tourism-related income in 2020.

\begin{tabular}{|c|c|c|c|c|c|c|c|}
\hline Category/Revenue & $\begin{array}{c}\text { HUF } \\
\text { 0-50 } \\
\text { Million } \\
\end{array}$ & $\begin{array}{c}\text { HUF } \\
\text { 50-250 } \\
\text { Million } \\
\end{array}$ & $\begin{array}{c}\text { HUF } \\
250-500 \\
\text { Million }\end{array}$ & $\begin{array}{c}\text { HUF } \\
\text { 500-1000 } \\
\text { Million }\end{array}$ & $\begin{array}{c}\text { HUF } \\
\text { 1000-5000 } \\
\text { Million }\end{array}$ & $\begin{array}{c}\text { HUF over } \\
5000 \\
\text { Million }\end{array}$ & Total \\
\hline $\begin{array}{l}1 \text { (municipalities without } \\
\text { significant attractiveness) }\end{array}$ & 338 & 118 & 11 & 3 & & & 470 \\
\hline $\begin{array}{c}2 \text { (municipalities with regional } \\
\text { attractiveness) }\end{array}$ & 18 & 28 & 8 & 14 & 11 & 1 & 80 \\
\hline $\begin{array}{c}3 \text { (municipalities with national, } \\
\text { international attractiveness) }\end{array}$ & 4 & 13 & 8 & 17 & 15 & 4 & 61 \\
\hline Total & 360 & 159 & 27 & 34 & 26 & 5 & 611 \\
\hline
\end{tabular}

Table 7. Number of municipalities located at a point not important for road traffic as a function of tourist attractiveness and OCR tourism-related income in 2020.

\begin{tabular}{|c|c|c|c|c|c|c|c|}
\hline Category/Revenue & $\begin{array}{c}\text { HUF } \\
0-50 \\
\text { Million }\end{array}$ & $\begin{array}{c}\text { HUF } \\
50-250 \\
\text { Million }\end{array}$ & $\begin{array}{c}\text { HUF } \\
250-500 \\
\text { Million }\end{array}$ & $\begin{array}{c}\text { HUF } \\
\text { 500-1000 } \\
\text { Million }\end{array}$ & $\begin{array}{c}\text { HUF } \\
\text { 1000-5000 } \\
\text { Million }\end{array}$ & $\begin{array}{c}\text { HUF over } \\
5000 \\
\text { Million }\end{array}$ & Total \\
\hline $\begin{array}{l}1 \text { (municipalities without } \\
\text { significant attractiveness) }\end{array}$ & 31 & 5 & & & & & 36 \\
\hline $\begin{array}{c}2 \text { (municipalities with regional } \\
\text { attractiveness) }\end{array}$ & 2 & 2 & 1 & & & & 5 \\
\hline $\begin{array}{l}3 \text { (municipalities with national, } \\
\text { international attractiveness) }\end{array}$ & 2 & 1 & 1 & & & & 4 \\
\hline Total & 35 & 8 & 2 & & & & 45 \\
\hline
\end{tabular}

This means (Table 8 ) that while invisible tourism was detected in $0 \%$ of the municipalities belonging to Category 3 (located at a point not important for road traffic), in Category 2 (existence of main roads), it was already $4-5 \%$, while in Category 1 (motorway slip roads) it was $14-16 \%$ of the 956 municipalities originally delimited (results for 2018 and 2019 are presented in Appendix A Table A8). In other words, in these cases, the correlation between tourism attractiveness and OCR data cannot be explained.

Table 8. Number of municipalities affected by invisible tourism as a function of road network characteristics in 2020.

\begin{tabular}{cccc}
\hline $\begin{array}{c}\text { Road Network } \\
\text { Characteristics }\end{array}$ & $\begin{array}{c}\text { Number of Municipalities } \\
\text { Affected by Invisible } \\
\text { Tourism }\end{array}$ & $\begin{array}{c}\text { Total Number of } \\
\text { Municipalities } \\
\text { Surveyed }\end{array}$ & $\%$ \\
\hline 1 & 42 & 300 & 14.00 \\
\hline 2 & 26 & 611 & 4.26 \\
\hline 3 & 0 & 45 & 0.00 \\
\hline Total & 68 & 956 & 7.11 \\
\hline
\end{tabular}

Sources: Own calculations, based on OCR register.

The results demonstrate that transit traffic generates significant invisible tourism revenue, primarily in municipalities with motorway slip roads and secondarily in municipalities bordering main roads (in municipalities with a large tourist attractiveness, these revenues are "visible", but for smaller ones, only the OCR data provide a guide). The lack of adequate connectivity practically excludes the emergence of invisible tourism. 


\section{Discussion}

Hungary is one of Europe's transit countries. It has a significant role in both EastWest and North-South passenger traffic on the continent. Transit passengers, most of who arrive by car, use motorways and/or trunk roads to cover the distance between two border sections, stopping off for a variety of needs. Transit is often disrupted in settlements where service providers have built their businesses specifically on transit. To ensure that these towns and villages are excluded from traditional tourism destinations, it is necessary to identify the characteristics that reliably indicate the likelihood of transit travel. This required the inclusion of a new data source (OCR) with sufficiently detailed spatial, temporal and activity level information to identify the tourism-related expenditure of transit travel. In the study, a geospatial delineation was carried out, based on which the groups were analysed according to their statistical characteristics It was assumed that a foreign transit passenger would also stop in a municipality that has no significant tourist attraction, but that its favourable location would contribute to its choice as a place for a break. Therefore, if a municipality located at the intersection of the shortest routes between border sections has above-average OCR tourism-related revenue, even though there is no significant tourism attraction, then the presence of transit traffic is probable. We were able to identify 86 municipalities that met the above criteria, which will be the focus of further research in the future.

We concluded that being located at the junction of a main road and a motorway or two main roads already has a significant impact on spending.

\section{Conclusions}

Overall, it can be concluded that the settlements that benefit most from the transit traffic of foreigners arriving in Hungary are those that:

- $\quad$ are located at the intersection of routes that allow the shortest time between each border section

- $\quad$ are located at the intersections of access from main roads to motorways, or at the junction of two main roads.

These results are certainly due to the psychological component of the nature of transit, in which intersections and nodes are seen as stages of the journey, the fulfilment of the desire to get somewhere, the physical completion of a stage (a well-deserved rest), and a place of preparation for the next stage.

We consider it important that the needs of the local residents and tourist service providers of the demarcated settlements, as well as transit passengers, be taken into account in spatial and transport planning. A complex approach is needed in order to ensure that the benefits of transit tourism do not only accrue to the service providers concerned, but also to minimize the damage or inconvenience it causes. Thus, instead of destroying tourist destinations, transit tourism becomes sustainable, even in the longer term. This, in turn, requires a holistic approach and long-term planning, the beginning of which we have tried to contribute to with our work.

Author Contributions: Conceptualization, G.T. and Á.K.; methodology, G.T. and Á.K.; validation, G.T. and Á.K.; formal analysis, G.T. and Á.K.; writing—original draft preparation, Á.K.; writingreview and editing, G.T. and Á.K.; visualization, G.T.; supervision, G.T. and Á.K. All authors have read and agreed to the published version of the manuscript.

Funding: The dissemination of research outcomes was supported by The Hungarian Tourism Association Foundation (MTSZ).

Institutional Review Board Statement: Not applicable.

Informed Consent Statement: Not applicable. 
Data Availability Statement: Data available on request due to restrictions privacy. The data presented in this study are available on request from the corresponding author. The data are not publicly available due to data protection aspects.

Conflicts of Interest: The authors declare no conflict of interest.

\section{Appendix A}

Table A1. Internationally recommended groupings of economic sectors related to tourism.

\begin{tabular}{|c|c|c|c|}
\hline $\begin{array}{l}\text { IRTS/TSA: RMF Tourism } \\
\text { Industries }{ }^{\text {a }}\end{array}$ & ISIC Rev. 4 & $\begin{array}{l}\text { NACE Rev. } 2 \\
\text { (TEÁOR'08) }^{b}\end{array}$ & Description (TEÁOR’08) \\
\hline \multirow{3}{*}{ Accommodation } & 5510 & 5510 & Hotels and similar accommodation \\
\hline & \multirow[t]{2}{*}{5520} & 5520 & Holiday and other short-stay accommodation \\
\hline & & 5530 & $\begin{array}{l}\text { Camping grounds, recreational vehicle parks and } \\
\text { trailer parks }\end{array}$ \\
\hline \multirow{4}{*}{$\begin{array}{l}\text { Food and beverage serving } \\
\text { activities }\end{array}$} & 5590 & 5590 & Other accommodation \\
\hline & 5610 & 5610 & Restaurants and mobile food service activities \\
\hline & 5629 & 5629 & Other food service activities \\
\hline & 5630 & 5630 & Beverage serving activities \\
\hline Railway passenger transport & 4911 & 4910 & Passenger rail transport, interurban \\
\hline \multirow{2}{*}{ Road passenger transport } & \multirow{2}{*}{4922} & 4932 & Taxi operation \\
\hline & & 4939 & Other passenger land transport \\
\hline \multirow{2}{*}{ Water passenger transport } & 5011 & 5010 & Sea and coastal passenger water transport \\
\hline & 5021 & 5030 & Inland passenger water transport \\
\hline Air passenger transport & 5110 & 5110 & Passenger air transport \\
\hline Renting and leasing of motor & \multirow[t]{2}{*}{7710} & 7711 & Renting and leasing of cars and light motor vehicles \\
\hline vehicles & & 7712 & Renting and leasing of trucks (over $3.5 \mathrm{t}$ ) \\
\hline \multirow{3}{*}{$\begin{array}{l}\text { Travel agency and tour } \\
\text { operator activities }\end{array}$} & 7911 & 7911 & Travel agency activities \\
\hline & 7912 & 7912 & Tour operator activities \\
\hline & 7990 & 7990 & Other reservation services and related activities \\
\hline \multirow{7}{*}{ Cultural activities } & 9000 & 9001 & Performing arts \\
\hline & & 9002 & Support activities to performing arts \\
\hline & & 9003 & Artistic creation \\
\hline & & 9004 & Operation of arts facilities \\
\hline & 9102 & 9102 & Museum activities \\
\hline & & 9103 & Operation of historical sites and buildings \\
\hline & 9103 & 9104 & $\begin{array}{c}\text { Botanical and zoological gardens and nature reserve } \\
\text { activities }\end{array}$ \\
\hline \multirow{6}{*}{$\begin{array}{l}\text { Sports and recreational } \\
\text { activities }\end{array}$} & 7721 & 7721 & Renting and leasing of recreational and sports goods \\
\hline & 9200 & 9200 & Gambling and betting activities \\
\hline & 9311 & 9311 & Operation of sports facilities \\
\hline & & 9313 & Fitness facilities \\
\hline & 9321 & 9321 & Activities of amusement parks and theme parks \\
\hline & 9329 & 9329 & Other amusement and recreation activities \\
\hline \multicolumn{4}{|c|}{ Country-specific tourism characteristic activities } \\
\hline Other personal service & & 9604 & Physical well-being activities \\
\hline activities (spa) & & 8690 & Other human health activities \\
\hline \multirow{3}{*}{$\begin{array}{l}\text { Support activities for } \\
\text { transportation }\end{array}$} & & 5221 & Service activities incidental to land transportation \\
\hline & & 5222 & Service activities incidental to water transportation \\
\hline & & 5223 & Service activities incidental to air transportation \\
\hline
\end{tabular}

a Source: International Recommendations for Tourism Statistics 2008-Annex 3. b TEÁOR'08 is the Hungarian activity classification identical to the European one, NACE Rev.2. Statistical Classification of Economic Activities in the European Community, 2008. 
Table A2. Number of municipalities with motorways and main roads as a function of tourist attractiveness and OCR tourism-related income in 2018.

\begin{tabular}{|c|c|c|c|c|c|c|c|}
\hline Category/Revenue & $\begin{array}{c}\text { HUF } \\
\text { 0-50 } \\
\text { Million }\end{array}$ & $\begin{array}{c}\text { HUF } \\
50-250 \\
\text { Million }\end{array}$ & $\begin{array}{c}\text { HUF } \\
250-500 \\
\text { Million }\end{array}$ & $\begin{array}{c}\text { HUF } \\
500-1000 \\
\text { Million }\end{array}$ & $\begin{array}{c}\text { HUF } \\
\text { 1000-5000 } \\
\text { Million }\end{array}$ & $\begin{array}{c}\text { HUF over } \\
5000 \\
\text { Million }\end{array}$ & Total \\
\hline $\begin{array}{l}1 \text { (municipalities without } \\
\text { significant attractiveness) }\end{array}$ & 111 & 66 & 15 & 10 & 6 & & 208 \\
\hline $\begin{array}{c}2 \text { (municipalities with regional } \\
\text { attractiveness) }\end{array}$ & 7 & 9 & 8 & 4 & 10 & 2 & 40 \\
\hline $\begin{array}{c}3 \text { (municipalities with national, } \\
\text { international attractiveness) }\end{array}$ & 5 & 5 & 4 & 5 & 19 & 14 & 52 \\
\hline Total & 123 & 80 & 27 & 19 & 35 & 16 & 300 \\
\hline
\end{tabular}

Table A3. Number of municipalities with main roads as a function of tourist attractiveness and OCR tourism-related income in 2018.

\begin{tabular}{ccccccc}
\hline Category/Revenue & $\begin{array}{c}\text { HUF } \\
\mathbf{0 - 5 0} \\
\text { Million }\end{array}$ & $\begin{array}{c}\text { HUF } \\
\mathbf{5 0 - 2 5 0} \\
\text { Million }\end{array}$ & $\begin{array}{c}\text { HUF } \\
\mathbf{2 5 0 - 5 0 0} \\
\text { Million }\end{array}$ & $\begin{array}{c}\text { HUF } \\
\mathbf{5 0 0 - 1 0 0 0} \\
\text { Million }\end{array}$ & $\begin{array}{c}\text { HUF } \\
\mathbf{1 0 0 0 - 5 0 0 0} \\
\text { Million }\end{array}$ & $\begin{array}{c}\text { HUF over } \\
\mathbf{5 0 0 0} \\
\text { Million }\end{array}$ \\
\hline $\begin{array}{c}\text { Total } \\
\text { significant attractiveness) }\end{array}$ & 338 & 114 & 16 & 2 & 470 \\
\hline $\begin{array}{c}\text { 2 (municipalities with regional } \\
\text { attractiveness) }\end{array}$ & 18 & 28 & 8 & 14 & 11 & 1 \\
\hline $\begin{array}{c}3 \text { (municipalities with national, } \\
\text { international attractiveness) }\end{array}$ & 4 & 13 & 8 & 16 & 60 \\
\hline Total & 360 & 155 & 32 & 32 & 61 \\
\hline
\end{tabular}

Table A4. Number of municipalities located at a point not important for road traffic as a function of tourist attractiveness and OCR tourism-related income in 2018.

\begin{tabular}{|c|c|c|c|c|c|c|c|}
\hline Category/Revenue & $\begin{array}{c}\text { HUF } \\
\text { 0-50 } \\
\text { Million }\end{array}$ & $\begin{array}{c}\text { HUF } \\
50-250 \\
\text { Million }\end{array}$ & $\begin{array}{c}\text { HUF } \\
250-500 \\
\text { Million }\end{array}$ & $\begin{array}{c}\text { HUF } \\
\text { 500-1000 } \\
\text { Million }\end{array}$ & $\begin{array}{c}\text { HUF } \\
\text { 1000-5000 } \\
\text { Million }\end{array}$ & $\begin{array}{c}\text { HUF over } \\
5000 \\
\text { Million }\end{array}$ & Total \\
\hline $\begin{array}{l}1 \text { (municipalities without } \\
\text { significant attractiveness) }\end{array}$ & 32 & 4 & & & & & 36 \\
\hline $\begin{array}{c}2 \text { (municipalities with regional } \\
\text { attractiveness) }\end{array}$ & 2 & 2 & 1 & & & & 5 \\
\hline $\begin{array}{c}3 \text { (municipalities with national, } \\
\text { international attractiveness) }\end{array}$ & 2 & 2 & & & & & 4 \\
\hline Total & 36 & 8 & 1 & & & & 45 \\
\hline
\end{tabular}


Table A5. Number of municipalities with motorways and main roads as a function of tourist attractiveness and OCR tourism-related income in 2019.

\begin{tabular}{|c|c|c|c|c|c|c|c|}
\hline Category/Revenue & $\begin{array}{c}\text { HUF } \\
\text { 0-50 } \\
\text { Million }\end{array}$ & $\begin{array}{c}\text { HUF } \\
50-250 \\
\text { Million }\end{array}$ & $\begin{array}{c}\text { HUF } \\
250-500 \\
\text { Million }\end{array}$ & $\begin{array}{c}\text { HUF } \\
500-1000 \\
\text { Million }\end{array}$ & $\begin{array}{c}\text { HUF } \\
\text { 1000-5000 } \\
\text { Million }\end{array}$ & $\begin{array}{c}\text { HUF over } \\
5000 \\
\text { Million }\end{array}$ & Total \\
\hline $\begin{array}{l}1 \text { (municipalities without } \\
\text { significant attractiveness) }\end{array}$ & 102 & 72 & 14 & 12 & 7 & 1 & 208 \\
\hline $\begin{array}{c}2 \text { (municipalities with regional } \\
\text { attractiveness) }\end{array}$ & 7 & 8 & 7 & 4 & 10 & 4 & 40 \\
\hline $\begin{array}{c}3 \text { (municipalities with national, } \\
\text { international attractiveness) }\end{array}$ & 5 & 5 & 3 & 6 & 18 & 15 & 52 \\
\hline Total & 114 & 85 & 24 & 22 & 35 & 20 & 300 \\
\hline
\end{tabular}

Table A6. Number of municipalities with main roads as a function of tourist attractiveness and OCR tourism-related income in 2019.

\begin{tabular}{|c|c|c|c|c|c|c|c|}
\hline Category/Revenue & $\begin{array}{c}\text { HUF } \\
\text { 0-50 } \\
\text { Million }\end{array}$ & $\begin{array}{c}\text { HUF } \\
\text { 50-250 } \\
\text { Million }\end{array}$ & $\begin{array}{c}\text { HUF } \\
250-500 \\
\text { Million }\end{array}$ & $\begin{array}{c}\text { HUF } \\
\text { 500-1000 } \\
\text { Million }\end{array}$ & $\begin{array}{c}\text { HUF } \\
\text { 1000-5000 } \\
\text { Million }\end{array}$ & $\begin{array}{c}\text { HUF over } \\
5000 \\
\text { Million }\end{array}$ & Total \\
\hline $\begin{array}{l}1 \text { (municipalities without } \\
\text { significant attractiveness) }\end{array}$ & 333 & 118 & 16 & 3 & & & 470 \\
\hline $\begin{array}{c}2 \text { (municipalities with regional } \\
\text { attractiveness) }\end{array}$ & 18 & 24 & 9 & 16 & 12 & 1 & 80 \\
\hline $\begin{array}{c}3 \text { (municipalities with national, } \\
\text { international attractiveness) }\end{array}$ & 4 & 13 & 5 & 14 & 19 & 6 & 61 \\
\hline Total & 355 & 155 & 30 & 33 & 31 & 7 & 611 \\
\hline
\end{tabular}

Table A7. Number of municipalities located at a point not important for road traffic as a function of tourist attractiveness and OCR tourism-related income in 2019.

\begin{tabular}{|c|c|c|c|c|c|c|c|}
\hline Category/Revenue & $\begin{array}{c}\text { HUF } \\
\text { 0-50 } \\
\text { Million }\end{array}$ & $\begin{array}{c}\text { HUF } \\
50-250 \\
\text { Million }\end{array}$ & $\begin{array}{c}\text { HUF } \\
250-500 \\
\text { Million }\end{array}$ & $\begin{array}{c}\text { HUF } \\
\text { 500-1000 } \\
\text { Million }\end{array}$ & $\begin{array}{c}\text { HUF } \\
\text { 1000-5000 } \\
\text { Million }\end{array}$ & $\begin{array}{c}\text { HUF over } \\
5000 \\
\text { Million }\end{array}$ & Total \\
\hline $\begin{array}{l}1 \text { (municipalities without } \\
\text { significant attractiveness) }\end{array}$ & 30 & 6 & & & & & 36 \\
\hline $\begin{array}{c}2 \text { (municipalities with regional } \\
\text { attractiveness) }\end{array}$ & 2 & 2 & 1 & & & & 5 \\
\hline $\begin{array}{c}3 \text { (municipalities with national, } \\
\text { international attractiveness) }\end{array}$ & 2 & 1 & 1 & & & & 4 \\
\hline Total & 34 & 9 & 2 & & & & 45 \\
\hline
\end{tabular}


Table A8. Number of municipalities affected by invisible tourism as a function of road network characteristics, 2018-2019.

\begin{tabular}{cccc}
\hline & \multicolumn{2}{c}{$\mathbf{2 0 1 8}$} & \\
\hline $\begin{array}{c}\text { Road Network } \\
\text { Characteristics }\end{array}$ & $\begin{array}{c}\text { Number of Municipalities } \\
\text { Affected by Invisible } \\
\text { Tourism }\end{array}$ & $\begin{array}{c}\text { Total Number of } \\
\text { Municipalities } \\
\text { Surveyed }\end{array}$ & $\%$ \\
\hline 1 & 43 & 300 & 14.33 \\
\hline 2 & 30 & 611 & 4.91 \\
\hline 3 & 0 & 45 & 0.00 \\
\hline Total & 73 & 956 & 7,64 \\
\hline Road Network & Number of Municipalities & Total Number of \\
Characteristics & Municipalities & Surveyed \\
\hline 1 & 48 & 300 & 16.00 \\
\hline 2 & 32 & 611 & 5.24 \\
\hline 3 & 0 & 45 & 0.00 \\
\hline Total & 80 & 956 & 8.37 \\
\hline
\end{tabular}

\section{References}

1. Puczkó, L.; Rátz, T. A Turizmus Hatásai; Aula-Kodolányi: Budapest, Hungary, 1998; ISBN 963-9345-11-3.

2. OECD. Implementing Online Cash Registers: Benefits, Considerations and Guidance OECD, Paris. 2019. Available online: www.oecd.org/tax/forum-on-tax-administration/publications-and-products/implementing-online-cash-registers-benefitsconsiderations-and-guidance.htm (accessed on 5 January 2022).

3. Leiper, N. The framework of tourism: Towards a definition of tourism, tourist, and the tourist industry. Ann. Tour. Res. 1979, 6, 390-407. [CrossRef]

4. Weaver, D.B.; Lawton, L.J. Tourism Management, 5th ed.; John Wiley \& Sons: Milton, QLD, Australia, 2014; ISBN 978-1-118-64481-2.

5. Hall, P.; Landis, J.; Cervero, R. Transit joint development in the USA: An inventory and policy assessment. Environ. Plan. C Govern. Policy 1991, 9, 431-452. [CrossRef]

6. Erdősi, F. Oroszország nemzetközi közlekedési infrastruktúráinak kényszerei, globális és regionális szerepei. Tér és Társadalom 2005, 19, 1-20. [CrossRef]

7. Kerschner, H.; Petrovitsch, H. Alpentransit auf der Schiene-das Beispiel Brennerachse. Geogr. Rundsch. 1998, 50, 580-586.

8. Kraus, M. Discomfort externalities and marginal cost transit fares. J. Urban. Econ. 1991, 29, 249-259. [CrossRef]

9. Fielding, G. Congestion pricing and the future of transit. J. Transp. Geogr. 1995, 3, 239-246. [CrossRef]

10. Bulis, A.; Skapars, R. Development of international freight transit in Latvia. Proced. Soc. Behav. Sci. 2013, 99, 57-64. [CrossRef]

11. Liu, Y.; Yang, L.; Chau, K.W. Impacts of Tourism Demand on Retail Property Prices in a Shopping Destination. Sustainability 2020, 12, 1361. [CrossRef]

12. Kalas, G. A déli tranzitautópálya csak alibi. Javaslat a déli tranzitautópálya hatásvizsgálataihoz, megvalósíthatósági tanulmány. ÖKO Ökológia Környezetgazdálkodás Társadalom 1992, 3, 30-38.

13. Fleischer, T. Transzeurópai folyosók: A meglévők hosszabbítgatása vagy egy összeurópai hálózat kialakítása? In Balkán és Magyarország: Váltás a Külpolitikai Gondolkodásban; Glatz, F., Ed.; MTA Társadalomkutató Központ Európa Intézet: Budapest, Hungary, 2007; pp. 365-379.

14. Ruppert, L. Az EU délkeleti irányú közlekedésének Magyarországot érintő hatásai. In Balkán és Magyarország: Váltás a Külpolitikai Gondolkodásban; Glatz, F., Ed.; MTA Társadalomkutató Központ Európa Intézet: Budapest, Hungary, 2007; pp. $357-363$.

15. Viton, P. Consolidations of scale and scope of urban transit. Reg. Sci. Urban. Econ. 1992, 22, 25-50. [CrossRef]

16. Knowles, R. Transit oriented development in Copenhagen, Denmark: From the Finger Plan to Ørestad. J. Transp. Geogr. 2012, 22, 251-261. [CrossRef]

17. Wang, Y.; Chen, H.; Wu, X. Spatial Structure Characteristics of Tourist Attraction Cooperation Networks in the Yangtze River Delta Based on Tourism Flow. Sustainability 2021, 13, 12036. [CrossRef]

18. Michalkó, G.; Rátz, T. Rejtett dimenziók a Kárpát-medence turizmusában. In Kárpát-Medence; Frisnyák, S., Gál, A., Eds.; Természet, Társadalom, Gazdaság Bocskai István Gimnázium, Nyíregyházi Főiskola Turizmus és Föld-rajztudományi Intézete: Szerencs, Hungary, 2013; pp. 463-476.

19. Kincses, Á.; Tóth, G.; Tömöri, M.; Michalkó, G. Characteristics of transit tourism in Hungary with a focus on expenditure. Reg. Stat. 2016, 6, 129-148. [CrossRef] 
20. Kincses, Á.; Tóth, G.; Tömöri, M.; Michalkó, G. Identifying settlements involved in Hungary's transit traffic. Reg. Stat. 2016, 6, 193-216. [CrossRef]

21. Kincses, Á.; Tóth, G.; Tömöri, M.; Michalkó, G. Az átutazó turizmus magyarországi sajátosságai, különös tekintettel a költésre. Területi Stat. 2016, 56, 455-476. [CrossRef]

22. Stetic, S.; Simicevic, D.; Stanic, S. Same-day trips: A chance of urban destination development. UTMS J. Econ. 2011, 2, 113-124. Available online: https://ideas.repec.org/a/ris/utmsje/0033.html (accessed on 10 October 2021).

23. Probáld, Á. (Ed.) Proceedings of the Sixth International Forum on Tourism Statistics; Hungarian Central Statistical Office, Services Statistics Department: Budapest, Hungary, 2002.

24. Bakic, O. Yugoslavian tourism: Strategic planning of destination product. Tour. Manag. 1988, 9, 145-151. [CrossRef]

25. Johnson, M. Czech and Slovak tourism: Patterns, problems and prospects. Tour. Manag. 1995, 16, 21-28. [CrossRef]

26. Baláz, V.; Mitsutake, M. Japanese tourists in transition countries of Central Europe: Present behaviour and future trends. Tour. Manag. 1998, 19, 433-443. [CrossRef]

27. Santos, M.; Radicchi, E.; Zagnoli, P. Port's Role as a Determinant of Cruise Destination Socio-Economic Sustainability. Sustainability 2019, 11, 4542. [CrossRef]

28. Achen, M.; Klein, K. Retail trade in transit areas: Introduction to a new field of research. Die Erde 2002, 133, 19-36.

29. McKercher, B.; Tang, E. The challenges of developing transit tourism. Asia Pac. J.Tour. Res. 2017, 9, 151-160. [CrossRef]

30. Tang, C.; Weaver, D.; Lawton, L. Can stopovers be induced to revisit transit hubs as stayovers? A new perspective on the relationship between air transportation and tourism. J. Air Transp. Manag. 2017, 62, 54-64. [CrossRef]

31. Poon, P.C.M.; Ho, G.K.S. Opportunities in Transit Tourism: A Case Study of Hong Kong as a Transit Destination. J. Travel Tour. Market. 2021, 38, 31-43. [CrossRef]

32. Ma, X.; Wu, Y.; Wang, Y.; Chen, F.; Liu, J. Mining smart card data for transit riders' travel patterns. Transp. Res. Part. C 2013, 36, 1-12. [CrossRef]

33. Green, F.B. Recreation vehicles: A perspective. Ann. Tour. Res. 1978, 5, 429-439. [CrossRef]

34. McElroy, J.L.; Albuquerque, K. Tourism penetration index in small Caribbean islands. Ann. Tour. Res. 1998, 25, 145-168. [CrossRef]

35. Michalkó, G. Turizmológia; Akadémiai Kiadó: Budapest, Hungary, 2012; ISBN 978-963-05-9717-3.

36. Cramer, H. Mathematical Methods of Statistics; Princeton University Press: Princeton, NJ, USA, 1946; ISBN 978-0-691-00547-8.

37. Everitt, B.S. The Cambridge Dictionary of Statistics; Cambridge University Press: Cambridge, UK, 2002; ISBN 978-0-521-76699-9.

38. Davenport, E.; El-Sanhury, N. Phi/Phimax: Review and Synthesis. Educ. Psychol. Meas. 1991, 51, 821-828. [CrossRef] 